\section{文献}

1）高橋健太郎, 大塚 淳, 羔協, 67 [4] 139-41 (1959).

2）大塚 㳯, 窝協, 73 [8] 170-180 (1965).

3）大塚 淳, 嘿協, 73 [9] 196-206 (1965).

4）大塚 淳, 窒協 70 [4] 110-13 (1962).

5) O.S. DuMont, H. Brokopf, K. Burkhardt, Z. anorg, allg. Chem., 295, 7-35 (1958).

6) D. Reinen, O.S. DuMont, ibid, 312, 121-34 (1961).

7）田中泰夫, 日化, 60 [2] 212-18, [3] 314-20, [10] 949 -57 (1939).

8) W. Büssem, C. Schusterius, A. Ungewiss, Ber. Deut. Keram. Ges., 18 [10] 433-43 (1937).

9) L.W. Coughanour, V.A. DeProsse, J. Res. Natl, Bur. Stand., 51 [2] 85-88 (1937).

10) W. Jander, K. Bunde, Z. anorg. allg. Chem., 239, 418-26 (1938).

11) L.W. Coughanour, R.S. Roth, S. Marzullo, J. Res. Natl. Bur. Stand., 54 [3] 155 (1955).

12) G. Yamaguchi, Bull. Chem. Soc. Japan, 26 [4]
204-206 (1953).

13) S.S. Cole, W.K. Nelsen, J. Phys. Chem., 42, 245 -51 (1938).

14) J.D. Dunitz, L.E. Orgel, J. Phys. Chem. Solds, 3, 20-29 (1957).

15）黑谷寿雄, 化学と工業, 15, 1132-41 (1962).

16) F.C. Romeijn, Philips Res. Rep., 8, 304-42 (1953).

17) J.B. Goodenough, A.L. Loeb, Phys. Rev., 98,391408 (1955).

18) A. Miller, J.Appl. Phys., 30 [4] 24 S-25 S (1959).

19) O.S. DuMont, Forschungsber. des Wirtschafts und Verkehrsministeriums Nordrhein-Westfalen, [193] 5 -37 (1955).

20) A. Ohtsuka, Bull. of the Fac. of Engng. Yokohama Natl. Univ. 11,15-20 (1962).

21) O.S. DuMont, H. Gössling, H. Brokopf, Z. anorg. allg. Chem., 300, 159-74 (1959).

(5/10/65 受付)

\title{
クロム系耐火物のバースチング現象 (1)
}

\author{
宗宫重行 \\ （東京工業大学工業材料研究所）
}

\section{The Bursting Phenomena of the Chrome Bearing Refractories (1)}

\author{
By \\ Shigeyuki SŌMIYA \\ (Research Institute of Engineerıng Materials, Tokyo Institute of Technology)
}

The bursting expansion is one of the important disintegrations of the chrome bearing refractories and has been studied by synthetic spinels, chrome ores and chrome spinel grains separated from chrome ores.

The mechanism of the bursting expansion is related to formation of solid solution and is one of the phenomena of the Kirkendall effect. (a) Formation of solid solution among spinel group minerals, (b) unequal diffusion coefficients of ions in the phases, (c) movement of Pt-mark in the sample, (d) displacement of Pt-mark during heating, inversely proportional to square root of diffusion time, (e) occurrence of pores in the refractories, and $(f)$ expansion after heat treatment and/or reaction are evidences for the fact that the bursting expansion is the Kirkendall effect. By adopting the Kirkendall effect ast he mechanism of the bursting, it is able to explain of pores and expansion after heat treatment.

The bursting expansions of synthetic spinel mixtures by a dilatometric method are divided into 3 types namely type $\mathrm{E}$, type $\mathrm{S}$ and type $\mathrm{L}$. Samples of the type E showed the bursting expansion, samples of the type $\mathrm{S}$ did not show the bursting expansion but showed shrinkage and samples of the type $\mathrm{L}$ showed a linear expansion up to $1600^{\circ} \mathrm{C}$.

In the case of the chrome spinel grains, there are 2 types of $\mathrm{E}$ and $\mathrm{S}$ for the bursting. The type $\mathrm{E}$ of the chrome spinel grains for the bursting belongs to the type $\mathrm{C}$ and $\mathrm{A}$ of TGA curves and the type $\mathrm{S}$ for the bursting showed TGA curve of the type $\mathrm{B}$. The type $\mathrm{C}$ showed the largest bursting expansion among 3 types of $\mathrm{A}, \mathrm{B}$ and $\mathrm{C}$ and the second expansion was shown by the type A. The type B did not show the bursting.

Chrome spinel grains of No. 5 Inazumi, No. 2 Imobara, No. 12 Hinokami No. 18 Cuba and No. 19 Masinloc belonged to the type B, No. 1 and No. 6 Wakamatsu belonged to the type A and No. 3 Hatta, No. 4 Tomimoto Shizunai, No. 7 Akaishi, No. 8 Philippine, No. 9 Philippine, No, 10 Hatta Main Mixture, No. 11 Tomimoto Nukahira, No. 13 Nitto, No. 14 Tsuchiya Horokanai, No. 15 Hatta Yawata, No. 16 Hatta Main, and No. 17 Nitto Washing belonged to the type $\mathrm{C}$. 
The bursting expansions of the 15 chrome ores by means of a bottom method were in the following order from large to small: No. 17 Nitto Washing, No. 13 Nitto, No. 10 Hatta Main Mixture, No. 9 Philippine, No. 1 Hirose, No. 6 Wakamatsu, No. 8 Philippine, No. 16 Hatta Main, No. 3 Hatta, No. 14 Tsuchiya Horokanai, No. 2 Imobara, No. 5 Inazumi, No. 7 Akaishi and the smallest No. 4 Tomimoto Shizunai.

Diffusion coefficients of ${ }^{59} \mathrm{Fe}$ at $1200^{\circ} \mathrm{C}$ and $1400^{\circ} \mathrm{C}$ in the system $\mathrm{MgO} \cdot \mathrm{Cr}_{2} \mathrm{O}_{3}$-iron oxide were $D_{1200}=2.89 \times 10^{-11} \mathrm{~cm}^{2} / \mathrm{sec}$ and $D_{1400}=3.69 \times 10^{-10} \mathrm{~cm}^{2} / \mathrm{sec}$, respectively.

We have to consider the following points as counterplans for the bursting expansion : (a) selection of chrome spinel grains from chrome ores, (b) content of chrome spinel grains in the refractory, (c) grain size, (d) calcination of chrome ore, (e) dense structure of the refractory, (f) porous structure and $(g)$ others.

[Received April 16, 1964]

\section{I. 緒言}

クロム系耐火物はクロム鉄鉱を主要な構成原料として おり，このクロム鉄鉱は等軸晶系のクロマイト $\mathrm{FeO}$ 。 $\mathrm{Cr}_{2} \mathrm{O}_{3}$, ピクロクロマイト $\mathrm{MgO} \cdot \mathrm{Cr}_{2} \mathrm{O}_{3}$, ヘルシナイト $\mathrm{FeO} \cdot \mathrm{Al}_{2} \mathrm{O}_{3}$, スピネル $\mathrm{MgO} \cdot \mathrm{Al}_{2} \mathrm{O}_{3}$, マグネタイト $\mathrm{FeO}$ - $\mathrm{Fe}_{2} \mathrm{O}_{3}$, マグネシオフェライト $\mathrm{MgO} \cdot \mathrm{Fe}_{2} \mathrm{O}_{3}$ などの固 溶しているスピネル族鉣物固溶体 “クロムスピネル粒”, $(\mathrm{Fe}, \mathrm{Mg}) \mathrm{O} \cdot(\mathrm{Cr}, \mathrm{Al}, \mathrm{Fe})_{2} \mathrm{O}_{3}$ と共に，夹雑鉣物として 蛇紋石 $3 \mathrm{MgO} \cdot 2 \mathrm{SiO}_{2} \cdot 2 \mathrm{H}_{2} \mathrm{O}$, 水滑石 $3 \mathrm{MgO} \cdot 4 \mathrm{SiO}_{2}$ • $\mathrm{H}_{2} \mathrm{O}$ ，オリビン $2(\mathrm{Mg}, \mathrm{Fe}) \mathrm{O} \cdot \mathrm{SiO}_{2}$ その他圭有してい る.

このクロム系耐火物はクロム鉄鉱の特質により，(1)珪 石質耐火物より遥加に高い耐火度を持つこと, (2)化学的 に中性であること，(3)侵蝕抵抗が割合大きいことなどの 利点があり，1880 年頃から，ヨーロッパで, 1905 年頃 から日本で，製鉄，製鋼工業に使用されて来た。

他方このクロム系耐火物の欠点としては，(1)高温にお ける収縮が大きい，(2)スポーリング抵抗が小さい，(3)荷 重軟化温度が低い，(4)ピーリングする。(5)バースチン グ*するなどである。

平炉の高温操業はクロム鉄鉱含有系塩基性耐火物の使 用を激堌せしめ, 現在までに幾多の研究報告が発表され て来た。クロム系耐火物と酸化鉄とのバースチングは， 1930１950 年にかけて製鋼用平炉ク口ム系耐火物損傷 の主因とみなされて，その原因と対策が研究されて来 た. 1950 年以後近年まで，このバースチング現象の研 究は，ク口ム系耐火物崩潰の主因がピーリングであると いら観点から困却されていたようであった。1955 年以 後ピーリング現象に関する研究の進展につれて, バース チングがピーリングの一原因であるという観点, 砕け易 いク口ム鉄鉱の体質改善研究，ク口ム系耐火物の侵蝕抵

*バースチングはクロム鉄鉱と酸化鉄が反応して異常膨皿 し，裂畩する現象である。バースチング (Bursting) と共 に，ブリーズイング (Breathing) といら言葉があるが, このブリーズイングはクロム鉄鉱中の酸化鉄が温度, 酸素 分压の変動在受けて $2 \mathrm{FeO}+1 / 2 \mathrm{O}_{2}=\mathrm{Fe}_{2} \mathrm{O}_{3}$ の反応が人間 が呼吸するように可逆的に起る現象で, 広義のバースチン グ現象中にブリーズイングは含まれるが，この報告内で， バースチングは狭義のクロム鉄鉱と外部から入る酸化鉄と の間で生起する反応とする。
抗に関する研究，金属における拡散現象の研究の発展に つれて,バースチング現象は再び注目され始めて来た。

クロム系耐火物を製鋼用平炬に使用する限り，クロム 系耐灭物と酸化鉄との反応, 平衡関係について研究する ことは重要な意義を有することと思う。著者はすでに Arnulf Muan と共㳊酸化鉄 $-\mathrm{Cr}_{2} \mathrm{O}_{3}$ 系, 酸化鉄 $-\mathrm{Al}_{2} \mathrm{O}_{3}$ $-\mathrm{Cr}_{2} \mathrm{O}_{3}$ 系, 酸化鉄 $-\mathrm{Cr}_{2} \mathrm{O}_{3}-\mathrm{SiO}_{2}$ 系, 酸化鉄- $\mathrm{MgO}$ 系 などの相平衡関係を明らかにした。

この報告の目的は，クロム系耐火物のバースチング機 構を検討し，原因を解明すると共に，耐火物として最良 のクロム鉄鉱選択上の知見を述べ，バースチング対策に ついて考察することにある。

多数のバースチング仮説を検討し，バースチング現象 の機構を明確にするために，クロム鉄鉱を使用してバー スチング現象の過程を追究していくことは夹雑鉱物が存 在していて複雑であり, 実験結果の解析が困難である。

著者はク口ム系耐火物に関係深い諸釷物をまず合成 し，この合成鉣物の膨脹を膨脹計により高温まで連続的 に測定すると共に，拡散現象としてバースチング現象を 解析し, クロムスピネル粒のバースチング性を追究し, さらにクロム鉄鉱のバースチング膨脹を求め, バースチ ング機構の一端を明らかにし, バースチング現象の防止 対策を指示した。

\section{II. バースチング現象の機構に関する既往の研究} バースチング現象はイギリスにおいて注目されて, 1934 年 Lynam and Rees ${ }^{11}$ により，クロム鉄鉱が酸化 鉄によって崩潰することが述べられた。この崩潰は鉄一 クロム系の固溶体生成によると考察した。 Hugill and Green ${ }^{2)}$ はクロムスピネル粒がマグネタイトを吸収し, 再結晶化の歪によって膨镺し，崩潰するというマグネタ イトの再結晶説をバースチングの機構として 1938 年に 提出した。

1937 年から 1939 年にかけてイギリスの Chesters 等 は種々の研究を発表し ${ }^{3) 455}$ ，始めバースチング機構は 耐火物中のクロムスピネル粒が蒸気をたは液体の酸化鉄 と固溶体をつくり，その際膨脹するといら単純固溶体説 (Simple Solid Solution Theory)であると発表した 
が, その後の研究の進展につれて, バースチング現象は (1)クロム鉄鉱のバースチング傾向が鉱石によって異な り，その差異が夹雑鉱物の種類と量によって説明されな いこと, (2)バースチング膨脹は試験雰囲気に影響を受 ける. (3) 塩基性スラッグによって膨脹するなどの理由 から,バースチング機構としての単純固溶体説の不完全 性を認め，バースチング機構は錯固溶体説 (Complex Solid Solution Theory) であると述べた。すなわらバ ースチングは

$$
\left[\begin{array}{l}
\mathrm{MgO} \cdot \mathrm{Al}_{2} \mathrm{O}_{3} \\
\mathrm{FeO} \cdot \mathrm{Cr}_{2} \mathrm{O}_{3}
\end{array}\right]+\mathrm{FeO} \cdot \mathrm{Fe}_{2} \mathrm{O}_{3} \rightarrow\left[\begin{array}{r}
\mathrm{MgO} \cdot \mathrm{Al}_{2} \mathrm{O}_{3} \\
\cdot \mathrm{Cr}_{2} \mathrm{O}_{3} \\
2 \mathrm{FeO} \cdot \mathrm{Fe}_{2} \mathrm{O}_{3}
\end{array}\right]
$$

$$
\text { 固体、液体、固体 }
$$

の高温反応で，複雑な錯固溶体生成のためにバースチン グ現象が起ることを説明した。

Trostel ${ }^{6}$ は 1939 年クロムスピネル粒と $\mathrm{MgO}$ の反 応について研究し, スピネル粒中には $\mathrm{R}^{\mathrm{I}} \mathrm{O}: \mathrm{R}_{2} \mathrm{I}^{\mathrm{I}} \mathrm{O}_{3}=1$

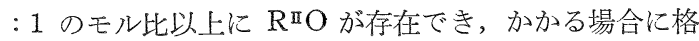
子の膨脹が認められることを指適し, バースチングは, $\mathrm{R}^{\mathrm{II}} \mathrm{O}$ が $\mathrm{R}^{\mathrm{I}} \mathrm{O}: \mathrm{R}_{2}{ }^{\mathrm{II}} \mathrm{O}_{3}=1: 1$ のモル比以上にスピネル 固溶体に吸収されるときに衫こるという固溶体格子膨脹 仮説を提出した.

1941 年 Hyslop ${ }^{7)}$ はクロマグ耐火物中の 珪酸塩結晶 が R $\mathrm{II}$ イオンと反応して低融点物質を生成し，この含鉄 理酸塩融液が耐火物中を通過し, 耐火物中の気孔の中で 固化結晶化する際膨脹し, 崩潰するという珪酸塩（融 液) 結晶化仮説をバースチング機構として提出した。 Hyslop はさらに研究を行ない, $\mathrm{FeO} や \mathrm{Fe}_{2} \mathrm{O}_{3}$ は $\mathrm{Fe}_{3} \mathrm{O}_{4}$ より小さいバースチング膨脹を与えることなどを報告し ている。

1946 年になって, Zerfoss and Davis ${ }^{8)}$ は今まで発表 されたバースチング 仮説を整理し，(1) 固溶体格子膨脹 仮説, (2) 珪酸塩結晶化仮説, (3) 磁鉄鉱のクロム核仮説 の 3 仮説をバースチング機構の仮説として述べ，これら 仮説の中では Jay and Chesters ${ }^{4}$ の提案した第 3 番目 の磁鉄鉱のクロム核仮説をもっとも確からしいと報告し ている.この仮説は磁鉄鉱のクロムスピネル粒を核とす るクロムスピネル粒上の成長をバースチングの機構とす るものである。

他方 Lovell, Rigby and Green は 1944 年 ${ }^{9)}, 1945$ 年 ${ }^{10)}$ のイギリス耐火物研究組合の非公開出版物を 1946 年になって公開した。彼らの研究結果をまとめてみると 下記のようになる。

(A) “FeO”による反応については, (1) $\mathrm{N}_{2}$ 気流中で $\mathrm{Cr}_{2} \mathrm{O}_{3}, \mathrm{Al}_{2} \mathrm{O}_{3}$ はクロマイト, ヘルシナイト生成のため 膨脹する, (2) $\mathrm{MgO}$ は膨脹しない, (3) $\mathrm{O}_{2}$ 存在下でスピ ネル族鉱物; クロム鉄鉱は膨脹を示すことを報告し, 膨 脹の原因としてマグネタイトの生成，マグネタイトとス
ピネル族鉣物間の反応という 2 因子を考えている.

(B) マグネタイトによる反応としては (1) $\mathrm{Cr}_{2} \mathrm{O}_{3}$, $\mathrm{Al}_{2} \mathrm{O}_{3}$ とは膨脹を示す, (2) $\mathrm{MgO}$ とは反応しても膨脹 を示さない, (3) スピネル族鉱物, クロム鉄鉱とは膨脹 を示す, (4) $\mathrm{Al}_{2} \mathrm{O}_{3}$, ヘルシナイト, スピネルは $\mathrm{Cr}_{2} \mathrm{O}_{3}$, クロマイト, ピクロクロマイトよりはそれぞれ低い膨脹 を示す, (5) クロム鉄鉱の 膨脹はクロムスピネル粒の化 学成分による。他の条件が同じならば $\mathrm{FeO}: \mathrm{MgO}$, $\mathrm{Cr}_{2} \mathrm{O}_{3}: \mathrm{Al}_{2} \mathrm{O}_{3}$ の比が大きいとバースチング膨膔が大き いと述べている。さらに

(C) 2 種のスピネル族鉱物間のバースチング膨脹は 固溶体が生成するまでおこらない。

(D) バースチング膨脹は固溶体生成にともならスピ ネル格子中の金属原子の再配列によっておこる。

（E）異なる結晶配列をとるスピネル族鉱物間のバー スチング脹膨は同種配列をとるスピネル族鉱物間の膨脹 より大きい。

これらの結果から， 正規型一逆型スピネル族鉣物固溶 体生成による原子再配列仮説を, バースチングの機構を 説明する説としている。

Trojer ${ }^{11}$ は 1951 年にバースチング膨脹は化学成分な どよりも粒子の大きさに影響を受けることを発表してい る.

Steele and Rigby' ${ }^{12) 1314)}$ などはバースチング膨脹を $\mathrm{Cr}^{3+}, \mathrm{Fe}^{3+}, \mathrm{Al}^{3+}, \mathrm{Fe}^{2+}, \mathrm{Mg}^{2+}$ などのスピネル族鉱物を構 成するイオンの拡散係数の差異により, Kirkendall 效 果が起り容積が 膨脹するという仮説で，1952 1956 年 にかけて説明している。

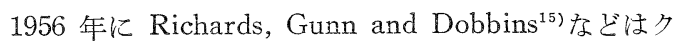
ロムスピネル粒の大きさがバースチング膨脹に与える影 響について論じ, Booth and Hedley ${ }^{16)}$ はクロム鉄鉱の 嵩比重とバースチング膨涱との間に直接的な関係はない が，焼成により嵩比重の減少する鉱石が大きいバースチ ング膨脹を示すと報告している。

Rigby and Richardson ${ }^{17}$ ) ，塩基性耐火物として重 要な性質は体積安定性とバースチング膨脹などであるこ とを述べている。

日本でも吉木 $(1943)^{18)}$ は電鋳クロマグ煉瓦を試作し て平炉飞使用し Chesters の固溶体生成説をバースチン グ現象の説として是認している，その後 1952 年には ${ }^{19)}$, バースチング機構としてクロム鉄鉱自体が磁鉄鉱固溶体 に変化し，しかる後成長するとして Chesters などのバ 一スチング機構と若干の所見の相異を持っているが大体 において Jay and Chesters の磁鉄鉱のクロム核仮説を 支持している.

山口 $(1953)^{20)}$ はクロム系耐火物の鉱物組成に関して 重液分離によって研究し, バースチングは不完全スピネ ルが，“FeO”を含む鉄スラッグと作用して完全スピネ 
ルに変化するために結晶が崩潰する現象としている.

尾野 $(1954)^{21}$ はバースチングとは酸化鉄が高温で液 相となって耐火物中のクロムスピネル粒に固溶体として 入り込むか, あるいは逆に液体酸化鉄が $\mathrm{MgO}, \mathrm{Al}_{2} \mathrm{O}_{3}$, $\mathrm{Cr}_{2} \mathrm{O}_{3}$ などを吸収してその温度で結晶化するために体積 膨脹を示す現象として説明している.

福井, 井出 $(1957)^{22)}$ は塩基性耐火物のバースチング 現象について研究をなし, バースチング仮説としてマグ ネタイトのクロム核仮説は首肯される点が多いが, マグ ネタイトは単にクロムスピネル粒上にこれを包んで成長 していくのではなく,クロムスピネル粒の鉄イオン吸収 によるマグネタイト化を経て再結晶的に生長していくも のとして, 不均等拡散説によりもっとも明瞭に説明出来 ると報告している.

尾山 $(1960)^{23)}$ は吉木, 福井などと異なり, バースチ ングの仮説としてクロムスピネル粒が酸化鉄を熔解して マグネタイト化し, その結果格子が膨脹し耐火物を崩潰 に導く格子膨脹仮説を支持している.

このようにバースチングの機構に関しては種々の仮説 が発表されているが，まだ確認されていない現状であ る.これらの仮説を整理してみると下記のようになる。

1. 固溶体格子膨脹仮説 (Trostel, 尾山など)

2. 珪酸塩融液結晶化仮説 (Hyslop)

3. 磁鉄鉱のクロム核仮説 (Jay, Chesters, Zerfoss and Davis)

4. 正規型一逆型スピネル 族鉱物固溶体生成による原 子再配列仮説 (Lovell, Rigby and Green)

5. 磁鉄鈗固溶体の生成とその成長化仮説 (Hugill and Green, 吉木)

6. 不完全スピネル族鉱物の完全化仮説 (山口)

7. Kirkendall 効果 (不均等拡散) 仮説 (Rigby など)

\section{III. バースチングの試験方法}

バースチング膨脹の試験方法としては, (1) 坩堝法,

(2)ボタン法, (3)混合法などに大別される.

坩堝法は坩堝型の容器を耐火物で作製し，その中に酸 化鉄をいれて試験し, 結果を外観, 切断面の観察, その 他によって判定する方法であり, Lynam and Rees $(1936)^{11}$ は容量 $15 \mathrm{cc}$, 高さ $41 \mathrm{~mm}$, 直径 $45 \mathrm{~mm}$ の坩堝 を使用し， $1600^{\circ} \mathrm{C} ， 4$ 時間で試験している.

ボタン法とは耐火物の上に酸化鉄の粉末成形物をのせ て試験するもので, 試験前後の上面の互に直角をなす 2 方向の膨脹率の平均，上面の互に直角をなす 2 方向と高 さの 3 方向の膨脹率の和あるいは平均で示す方法であ り, Hugill and Green $(1938)^{2)}$ は, 直径 $1^{\prime \prime}$, 高さ $1^{\prime \prime}$ のミルスケールをのせて $1550^{\circ} \sim 1580^{\circ} \mathrm{C}$ に 3 時間加熱し て試験している. 耐火物試料の大きさは種々あり, 円形 あるいは角形である。
混合法とは試料と酸化鉄，あるいは 2 種以上の粉末を よく混合し，その成形物を加熱して長さの変化を測定し ていく方法であり, Lovell, Rigby, and Green $(1946)^{10}$ は直径 $1.8 \mathrm{~cm}$, 高さ $2 \mathrm{~cm}$ の大きさに合成スピネル族鉣 物の混合物を成形し, $800^{\circ} \sim 1200^{\circ} \mathrm{C}$ 間の一定温度に 2 時 間保持し，その膨脹収縮を測定している.

これら 3 方法のらちボタン法が一番多く試験方法とし て採用されており，(1) 酸化鉄としてロールスケール， $\mathrm{Fe}_{2} \mathrm{O}_{3}, \mathrm{Fe}+\mathrm{Fe}_{2} \mathrm{O}_{3}$ などであり，その量は $0.74 \sim 1.8 \mathrm{~g}$ $\mathrm{Fe}_{2} \mathrm{O}_{3} / \mathrm{cm}^{2}$ が多い. (2) 上表面が $50 \times 50 \mathrm{~mm}^{2}$ のもの, あるいは直径 $50 \mathrm{~mm}$ くらいの大きさの試験体が多く採 用されている. (3) 試験温度は $1600^{\circ} \sim 1700^{\circ} \mathrm{C}$ が多く, $1500^{\circ} \mathrm{C}$ で試験する場合には $\mathrm{CaO}$, 塩基性スラッグなど を酸化鉄に添加して使用する例が多い. (4) 最高温度に 保持する時間は $1 \sim 3$ 時間が多い. (5)膨脹率は試験前後 の上面の互に直角な 2 方向の平均，さらに高さを加えて 3 方向の平均, あるいは 3 方向膨脹率の和で示してい る.

3 試験方法の特徴を考えてみると下記のようになると 思う。坩堝法は試験中に酸化鉄が流出しない利点があ り, 試験結果の判定が定性的であり, 耐火物の原表面を 利用しないことなどが久点である．ボタン法は (1) 耐火 物の原表面が利用出来ること, (2) 耐火物の 組織とバ一 スチングの関倸を重視するときによい，(3) 試験結果が 定量的に示されるなどの利点があると同時に，欠点とし て (1) 酸化鉄流出の危険性, (2) 実験結果の再現性の困 難性などがある。混合法は (1) 化学成分とバースチング 量を研究するによい，(2) 結果は定量的である，(3) 電気 炉使用なので, 温度, 雲囲気の調節がガス炬より容易であ る，(4) 試料の上表面から試料下面へと液体が侵透する 過程を含まないので，侵透の深さや試料の組織によらな い, (5) 試料の上表面上で酸化鉄が熔融し，その結果発 生する割れ目，裂け目の影響を除くことができる，6 液体の結晶化によるバースチング膨脹を除去できること などが利点であり，(1) 耐火物の原表面を利用出来な い，(2) 耐火物の組織的構成に 関係しない，などが欠点 である。

\section{IV. 試料と実験方法}

バースチング膨脹について, 再現性のある結果が得ら れる実験条件を決定したボタン法と, 高温熱膨脹計を使 用した混合法を採用して実験し，さらにラジオアイソト 一プによって拡散係数を求め, バースチング機構を解明 した.

\section{(1) 試 料の調 整}

（a）合成鉱物 クロマイト，ピクロクロマイト， スピネル, ヘルシナイト, マグネシオフェライトなどの スピネル族鉱物，フォルステライト，モンチセライト， 
エンスタタイトなどの珪酸塩鉱物をそれぞれ酸化物, 炭 酸塩などから合成した.スピネルその他珪酸塩釷物の合 成方法，性質については既に報告した ${ }^{24)}$.上記鉣物のう ちクロマイト, ヘルシナイトについては $\mathrm{Fe}_{2} \mathrm{O}_{3}: \mathrm{Cr}_{2} \mathrm{O}_{3}$ $=1: 3, \mathrm{Fe}_{2} \mathrm{O}_{3}: \mathrm{Al}_{2} \mathrm{O}_{3}=1: 3$ (モル比) になるように秤 量, 混合し， $1500^{\circ} \mathrm{C}, 3$ 時間ガス炉焼成し，48メッ シュ全通物にして $1200^{\circ} \mathrm{C}, 2$ 時間電気炬焼成し，この焼 成物を微粉砕して $\mathrm{Fe}$ 粉末をクロマイト，ヘルシナイト になるようにそれぞれ添加混合し，高周波電気炬を使用 してアルゴン雾囲気中で $1400^{\circ} \mathrm{C}, 1$ 時間加熱し，焼成物 を $\mathrm{X}$ 線で同定して合成した.

マグネタイトは釜石鈗山産の磁鉄鉣を微粉砕し, $\mathrm{HCl}$ で不純物除去を行なったもので， $\mathrm{FeO} 30.75 \%, \mathrm{Fe}_{2} \mathrm{O}_{3}$ $67.84 \%$ のものである。

抬散実験に使用した放射性酸化鉄は, Fe として $0.59 \mathrm{~g}$ を含む $\mathrm{FeCl}_{3}$ に $10 \mu \mathrm{c} の \mathrm{Fe}^{*} \mathrm{Cl}_{3}$ を添加し, $\mathrm{NH}_{4} \mathrm{OH}$ で 水酸化鉄として沈澱させ, 滤過洗涤し, $105^{\circ} \sim 110^{\circ} \mathrm{C}$ で 乾燥させ, $500^{\circ} \mathrm{C} に 5$ 時間炍焼して水分を揮発させ, ${ }^{59} \mathrm{Fe}$ を含む酸化鉄を得た。

（b）クロム鉄鉱 入手したクロム鉄鉱は 表-1 に 示した通り 19 種で, 地名を示した。塊鉱はジョークラ ッシャ一，ロールクラッシャーで粉砕した. 試料は 20 〜180メッシュのものを使用した。表-2 に使用したク 口ム鉄鉣の化学組成を示した。 $\mathrm{SiO}_{2}$ は $19.00 \%$ (No. 12 日野上) 2.42\% (No. 17 日東水洗), $\mathrm{Al}_{2} \mathrm{O}_{3}$ は $32.50 \%$ (No. 19 マシンロック) $2.40 \%$ (No. 17 日 東水洗) $\mathrm{Cr}_{2} \mathrm{O}_{3}$ は $60.78 \%$ (No. 17 日東水洗) 13.99 $\%$ (No. 4 富本静内), $\mathrm{FeO}$ (全鉄分を $\mathrm{FeO}$ として示し たもの) は $22.10 \%$ (No. 17 日東水洗) 〜 7.96\% (No. 5 稲積)， $\mathrm{MgO}$ は $24.92 \%$ (No. 5 稻積) 10.05\% (No. 17 日東水洗) の範囲を含むものであり，産地によ って化学成分は大いに異なり，夹雑鉱物もそれぞれ異な っているが, 蛇紋岩, 水滑石, 炭酸塩などを含んでい
Table 1. Locality of chrome ores used.
No. Name of mine

1 Hirose

2 Imobara

3 Hatta

4 Tomimoto Shizunai

5 Inazumi

6 Wakamatsu

7 Akaishi

8 Philippine

9 Philippine

10 Hatta Main Mixture

12 Hinokami

13 Nitto

14 Tsuchiya Horokanai

16 Hatta Main

17 Nitto Washing

18 Cuba

19 Masinloc
11 Tomimoto Nukahira
15 Hatta Yawata

Locality

Tari-mura, Hino-gun, Tottori-ken, Japan

Imobara, Kamiichi-machi, Atetsu-gun Okayama-ken, Japan

Furenai, Horosaru-mura, Hiratori-ma chi, Saru-gun, Hidaka, Hokkaido, Japan

Takami, Shizunai-machi, Shizunai-gun, Hidaka, Hokkaido, Japan

Hinokami-mura, Hino-gun, Tottoriken, Japan

Tari-mura, Hino-gun, Tottori-ken, Japan

Sekikawa-mura, Uma-gun, Ehime ken, Japan

Unknown, through Nanyo Bussan K.K. Unknown, through Santo Shoji K.K.

Furenai, Horosaru-mura, Hiratormachi, Saru-gun, Hidaka, Hokkaido, Japan

Nukkibetsu, Hiratori-machi, Saru-gun, Hidaka, Hokkaido, Japan

Hinokami-mura, Hino-gun, Tottoriken, Japan

Niseu, Hiratori-machi, Saru-gun, Hidaka, Hokkaido, Japan

Horokanai, Uryu-gun, Teshio, Hokka. ido, Japan

Hobetsu-machi, Yufutsu-gun, Iburi, Hokkaido, Japan

Furenai, Horosaru-mura, Hiratorimachi, Saru-gun, Hidaka, Hokkaido, Japan

The same as No. 13

Unknown

Philippine

る。例えば代表的なクロム鉄鉣の顕微鏡写真図を図-1 に示した。 No. 1 広瀬クロム鉄鉱は，夹雑鉣物として 蛇紋岩を主としそれに少量の炭酸塩などからなり，ク口 ムスピネル粒の外周には黒色の酸化鉄の存在が認められ る.No. 4 富本静内鉣は約 $60 \%$ くらいが肉眼的にみて 不純物であり，水滑石を多量に含み，他に蛇紋岩があ る.No. 9 比島は蛇紋岩などを主にするが，クロムスピ ネル粒は大形のものが多く，割目に黒色の酸化鉄が認め られる。

クロム鉄鉱中のクロムスピネル粒量と夹雑鉱物との量 はクロム鉄鉱中の $\mathrm{Cr}_{2} \mathrm{O}_{3}$ 量と, 後記のクロムスピネル
Table 2. Chemical compositions of chrome ores.

$\begin{aligned} \text { No. } 1 & \text { Hirose } \\ 2 & \text { Imobara } \\ 3 & \text { Hatta } \\ 4 & \text { Tomimoto Shizunai } \\ 5 & \text { Inazumi } \\ 6 & \text { Wakamatsu } \\ 7 & \text { Akaishi } \\ 8 & \text { Philippine } \\ 9 & \text { Philippine } \\ 10 & \text { Hatta Main Mixture } \\ 11 & \text { Tomimoto Nukahira } \\ 12 & \text { Hinokami } \\ 13 & \text { Nitto } \\ 14 & \text { Tsuchiya Horokanai } \\ 15 & \text { Hatta Yawata } \\ 16 & \text { Hatta Main } \\ 17 & \text { Nitto Washing } \\ 18 & \text { Cuba } \\ 19 & \text { Masinloc } \\ & \text { * Total iron as FeO }\end{aligned}$

$\begin{array}{rrr}\mathrm{H}_{2} \mathrm{O}^{-} & \begin{array}{c}\mathrm{H}_{2} \mathrm{O}^{+} \\ (\%)\end{array} & \begin{array}{r}\mathrm{SiO}_{2} \\ (\%)\end{array} \\ 0.25 & 1.82 & 4.72 \\ 0.19 & 0.36 & 10.04 \\ 0.64 & 2.10 & 5.34 \\ 2.00 & 11.84 & 12.10 \\ 0.56 & 5.34 & 9.92 \\ 0.22 & 3.01 & 5.50 \\ 0.40 & 4.10 & 8.82 \\ 0.54 & 3.15 & 13.54 \\ 0.31 & 1.49 & 3.84 \\ 0.21 & 1.84 & 7.64 \\ 0.40 & 2.20 & 12.00 \\ 0.18 & 8.32 & 19.00 \\ 0.17 & 2.53 & 5.60 \\ 0.24 & 2.53 & 7.50 \\ 0.24 & 2.67 & 8.32 \\ 0.28 & 2.00 & 5.94 \\ 0.10 & 2.46 & 2.42 \\ & 2.59 & 3.75 \\ & & 4.10\end{array}$

\begin{tabular}{cccc}
$\mathrm{CaO}$ & $\mathrm{TiO}_{2}$ & \multicolumn{1}{c}{$\begin{array}{c}\mathrm{FeO} \\
(\%)\end{array}$} & $\begin{array}{c}\mathrm{MgO} \\
(\%)\end{array}$ \\
0.07 & 1.26 & 12.36 & 17.82 \\
tr. & 0.76 & 13.69 & 24.86 \\
0.69 & 0.48 & 13.29 & 15.35 \\
tr. & 7.30 & 11.57 & 22.15 \\
tr. & 1.36 & 7.96 & 24.92 \\
0.07 & 0.80 & 13.55 & 18.31 \\
tr. & 0.84 & 14.31 & 17.48 \\
tr. & 0.67 & 14.44 & 15.78 \\
tr. & 1.27 & 16.10 & 17.37 \\
- & 0.64 & 14.48 & 22.11 \\
tr. & 0.26 & 9.61 & 14.67 \\
tr. & 0.33 & 9.72 & 21.60 \\
tr. & 0.84 & 13.26 & 18.69 \\
- & 0.40 & 16.02 & 17.46 \\
tr. & 0.88 & 13.04 & 14.24 \\
tr. & 0.46 & 13.15 & 19.12 \\
- & 0.40 & 22.10 & 10.05 \\
& & 13.52 & 16.98 \\
& & 12.28 & 18.67
\end{tabular}


(a)

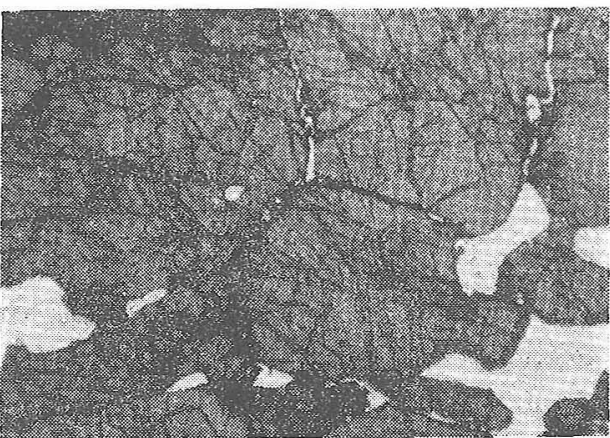

(b)

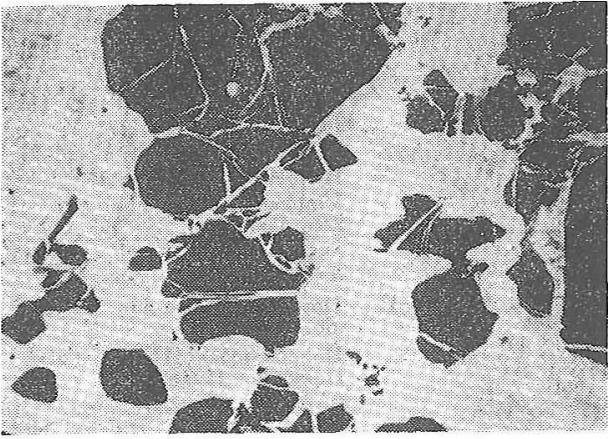

(c)

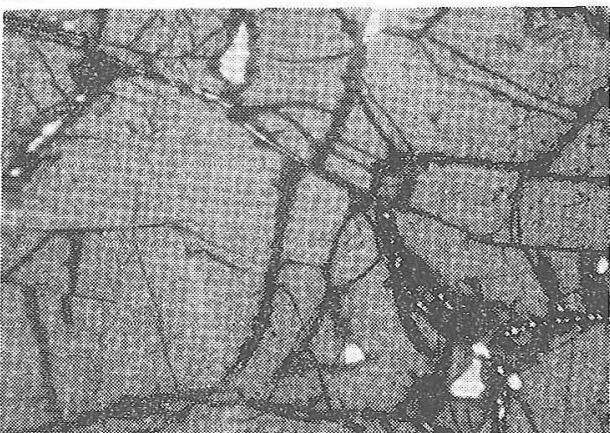

Fig. 1. Photomicrographs of (a) No. 1 Hirose Chrome Ore, (b) No. 4 Tomimoto Shizunai Chrome Ore, and (c) No. 9 Philippine Chrome Ore. $(\times 100)$

粒中の $\mathrm{Cr}_{2} \mathrm{O}_{3}$ 量の比によって, 化学的に推定した，結果は 表-3 であり，もっとも多量にクロムス ピネル粒を含有子る鉱石はNo.9 比島の $96.3 \%$ であり，もっとも 多量に不純物を含むものは No.4 富本静内鉱で $71.0 \%$ である*。

バースチング試験に使用したク ロム鉄鉱の粒度は，ボタン法の場 合タイラー穊の 20〜180 メッシュ であり，混合法の埸合には試験体 の大きさがボタン法よりも小さい ので 100〜180メッシュであっ た。

*クレリシ重液によってクロム鉄鉱の 変質はないと级定した。 （c）クロムスピネル粒・クレリシ重液及び融剤に よってクロム鉄鉣加ら分離した．融郕の選択については 著者が既に辫告したように占) $\quad \mathrm{Na}_{2} \mathrm{CO}_{3}, \mathrm{KOH}+\mathrm{NaOH}$ $(1: 1), \mathrm{KOH}+\mathrm{NaOH}+\mathrm{K}_{2} \mathrm{CO}_{3}+\mathrm{Na}_{2} \mathrm{CO}_{3}(6: 4: 5: 5)$ の3種のらちから，融郕によって分離したクロムスピネ 儿粒の化学成分と熱天秤図がクレリシ重液によって分離 したクロムスピネル粒の性質上似ている $\mathrm{KOH}+\mathrm{NaOH}$ $+\mathrm{K}_{2} \mathrm{CO}_{3}+\mathrm{Na}_{2} \mathrm{CO}_{3}(6: 4: 5: 5)$ を融剤として選んだ.

クレリシ重液による場合 100〜200 メッシュ微粉クロ ム鉄鉱を使用して遠心分離器によりク口ムスピネル粒を 分離した。粒の化学成分は 表-4 に示した.

融剤の場合， $\mathrm{KOH}+\mathrm{NaOH}+\mathrm{K}_{2} \mathrm{CO}_{3}+\mathrm{Na}_{2} \mathrm{CO}_{3}(6: 4$ : 5:5) 在約 $2.5 \mathrm{~g}$, 所定の重量比に秤量し，100 200 メッシュクロム鉄鉣 $5 \mathrm{~g}$ 学徐々に加えで熔融する。10 分 間保持した後泠却，融塊を温湯で処理し，不熔解部分を 抽出し数回傾泻して洗涤する。この操作をさらに 1 回繰

Table 3. Amounts of chrome spinel grains and gangue minerals in the chrome ores.

No. 1 Hìrose

$\begin{array}{cc}\begin{array}{c}\text { Amount of } \\ \text { chrome spinel } \\ \text { grains (\%) }\end{array} & \begin{array}{c}\text { Amount of } \\ \text { gangue } \\ \text { minerals }(\%)\end{array} \\ 96.0 & 4.0 \\ 68.0 & 32.0 \\ 89.5 & 10.5 \\ 29.0 & 71.0 \\ 70.2 & 29.8 \\ 81.2 & 18.8 \\ 80.1 & 19.9 \\ 90.4 & 9.6 \\ 96.3 & 3.7 \\ 91.8 & 8.2 \\ 82.0 & 18.0 \\ 65.2 & 34.8 \\ 91.5 & 8.5 \\ 70.5 & 29.5 \\ 84.1 & 15.9 \\ 81.2 & 18.8 \\ 96.0 & 4.0 \\ 81.9 & 18.1 \\ 92.9 & 7.1\end{array}$

Table 4. Chemical compósitions of the chrome spinel grains separated

\begin{tabular}{|c|c|c|c|c|c|c|c|}
\hline & & $\underset{(\%)}{\mathrm{SiO}_{2}}$ & $\underset{(\%)}{\mathrm{MgO}}$ & $\begin{array}{c}\mathrm{FeO}_{(\%)} \\
(\%)\end{array}$ & $\begin{array}{c}\mathrm{Cr}_{2} \mathrm{O}_{3} \\
(\%)\end{array}$ & $\underset{(\%)}{\mathrm{Al}_{2} \mathrm{O}_{3}}$ & $\begin{array}{c}\text { Total } \\
(\%)\end{array}$ \\
\hline 0. 1 & Hirose & 2.17 & 17.77 & 13.57 & 35.46 & 30.08 & 99.06 \\
\hline 2 & Imobara & 4.60 & 16.22 & 20.11 & 39.42 & 20.06 & 100.41 \\
\hline 3 & Hatta & 2.00 & 14.79 & 15.59 & 54.34 & 15.28 & 101.00 \\
\hline 4 & Tomimoto Shizunai & 3.43 & 15.77 & 18.46 & 48.27 & 14.85 & 100.78 \\
\hline 5 & Inazumi & 1.33 & 17.39 & 15.01 & 38.16 & 31.30 & 103.19 \\
\hline 6 & Wakamatsu & 1.80 & 16.20 & 17.02 & 30.20 & 28.40 & 101.60 \\
\hline 7 & Akaishi & 1.23 & 9.27 & 26.70 & 55.24 & 8.70 & 101.14 \\
\hline 8 & Philippine & 2.00 & 13.76 & 16.85 & 49.08 & 15.73 & 97.42 \\
\hline 9 & Philippine & 1.10 & 14.12 & 18.10 & 50.00 & 16.38 & 99.70 \\
\hline 10 & Hatta Main Mixture & 2.60 & 15.62 & 15.56 & 46.99 & 23.13 & 103.90 \\
\hline 11 & Tomimoto Nukahira & 4.86 & 12.31 & 13.93 & 52.63 & 17.68 & 101.31 \\
\hline 12 & Hinokami & 2.30 & 12.98 & 17.05 & 51.07 & 16.35 & 99.75 \\
\hline 13 & Nitto & 2.37 & 14.05 & 14.97 & 56.73 & 13.09 & 101.21 \\
\hline 14 & Tsuchiya Horokanai & 0.23 & 8.33 & 22.28 & 63.37 & 11.18 & 105.89 \\
\hline 15 & Hatta Yawata & 2.33 & 15.28 & 15.78 & 52.42 & 16.09 & 101.90 \\
\hline 16 & Hatta Main & 4.31 & 16.11 & 14.74 & 49.96 & 13.78 & 99.90 \\
\hline 17 & Nitto Washing & 2.33 & 13.72 & 16.70 & 58.28 & 9.86 & 100.89 \\
\hline 18 & Cuba & 1.48 & 15.87 & 14.77 & 39.88 & 31.28 & 103.28 \\
\hline 19 & Masinloc & 0.38 & 17.71 & 13.45 & 35.14 & 39.65 & 106.33 \\
\hline
\end{tabular}

3 Hatta

4 Tomimoto Shizunai

5 Inazumi

6 Wakamatsu

7 Akaishi

8 Philippine

9 Philippine

10 Hatta Main Mixture

11 Tomimoto Nukahira

12 Hinokami

13 Nitto

14 Tsuchiya Horokanai

15 Hatta Yawata

16 Hatta Main

17 Nitto Washing

18 Cuba

19 Masinloc

\section{from the chrome ores by Clerici heavy liquid.}


Table 5. Chemical compositions of the chrome spinel grains separated from the chrome ores by the flux, $\mathrm{KOH}+\mathrm{NaOH}+\mathrm{K}_{2} \mathrm{CO}_{3}+\mathrm{Na}_{2} \mathrm{CO}_{3}$ $(6: 4: 5: 5)$.

\begin{tabular}{|c|c|c|c|c|c|c|c|}
\hline & & $\underset{(\%)}{\mathrm{SiO}_{2}}$ & $\underset{(\%)}{\mathrm{MgO}}$ & $\begin{array}{c}\mathrm{FeO}_{(\%)}^{*} \\
(\%)\end{array}$ & $\begin{array}{c}\mathrm{Cr}_{2} \mathrm{O}_{3} \\
{ }_{3}(\%)\end{array}$ & $\frac{\mathrm{Al}_{2} \mathrm{O}_{3}}{(\%)}$ & $\begin{array}{c}\text { Total } \\
(\%)\end{array}$ \\
\hline No. 1 & Hirose & 0.16 & 12.36 & 13.36 & 38.18 & 35.03 & 102.75 \\
\hline 2 & Imobara & 0.54 & 11.88 & 16.00 & 55.92 & 14.45 & 98.79 \\
\hline 3 & Hatta & 0.08 & 13.00 & 15.10 & 63.83 & 12.82 & 104.83 \\
\hline 4 & Tomimoto Shizunai & 0.16 & 13.11 & 18.19 & 58.52 & 13.05 & 104.01 \\
\hline 5 & Inazumi & 0.52 & 13.74 & 16.29 & 38.93 & 28.65 & 98.13 \\
\hline 6 & Wakamatsu & 0.40 & 15.30 & 15.95 & 39.71 & 28.40 & 99.76 \\
\hline 7 & Akaishi & 0.24 & 8.91 & 25.89 & 56.06 & 7.43 & 98.53 \\
\hline 8 & Philippine & 0.18 & 10.92 & 16.75 & 57.45 & 17.10 & 102.40 \\
\hline 9 & Philippine & 0.22 & 14.86 & 18.19 & 55.44 & 11.10 & 99.81 \\
\hline 10 & Hatta Main Mixture & 0.08 & 14.48 & 15.08 & 54.56 & 16.00 & 100.20 \\
\hline 11 & Tomimoto Nukahira & 2.24 & 11.59 & 13.26 & 62.87 & 9.85 & 99.81 \\
\hline 12 & Hinokami & 0.32 & 17.26 & 16.11 & 42.08 & 26.00 & 101.77 \\
\hline 13 & Nitto & 0.10 & 14.48 & 15.64 & 61.21 & 10.25 & 101.68 \\
\hline 14 & Tshuchiya Horokanai & 1.88 & 8.41 & 20.92 & 62.12 & 10.33 & 103.66 \\
\hline 15 & Hatta Yawata & 0.10 & 8.72 & 15.92 & 55.87 & 18.35 & 98.97 \\
\hline 16 & Hatta Main & 0.64 & 15.50 & 16.07 & 55.26 & 14.28 & 101.75 \\
\hline 17 & Nitto Washing & 0.20 & 11.23 & $15 \cdot 73$ & 63.33 & 12.65 & 103.14 \\
\hline 18 & Cuba & 0.20 & 15.92 & 14.15 & 35.81 & 29.95 & 96.03 \\
\hline 19 & Masinloc & 0.65 & 17.71 & 12.92 & 35.14 & 34.50 & 100.82 \\
\hline
\end{tabular}

$1200^{\circ} \mathrm{C}$ ，あるいは $1400^{\circ} \mathrm{C}$ に加熱 して白金線の移動を測定すると共 に，一定時間後に実験後の試料を 樹脂でかため中心から切断し, 切 断面を研磨しセロイジン $1 \%$ 液 学塗り, 泠所で一尽夜乾燥させ, 化学カブリを防ぐようにし，コン タクト法用富士オートラジオグラ フ乾板膜厚 $15 \mu$ の $\mathrm{ET}-2 \mathrm{E}$ 型学 使用し，10 日間冷所のデシケー ター (乾燥剤は塩化カルシウム) 中で露出し, 感光せしめ, FD111 の処方により $2 \sim 4$ 分間現 像した。フィルムの黒化度はミク ロホトメーターで測定した。走査 測度は $1.0 \mathrm{~mm} / \mathrm{min}$ であった。

\section{V. 実 験 結、果}

\section{（1）混合物の高温膨脹計法によるバースチング}

高温膨脹計による結果は 表-6, 困-2 に示した。これ らの結果を分類すると， $\mathrm{E}$ 型： $1000^{\circ} \sim 1200^{\circ} \mathrm{C}$ から急激 なバースチング膨脹を示す場合, $\mathrm{S}$ 型 : $1200^{\circ} \sim 1400^{\circ} \mathrm{C}$ の範囲内からバースチング膨脹を示さずに収縮過程に入

\section{(2) 実 験 方 法}

(a) ボタン法による実験２0１80メッシュクロ ム 鉄鉱粉末に Carbowax 4000 を $2 \%$ 添加し, $5 \%$ の水分で $1000 \mathrm{~kg} / \mathrm{cm}^{2}$ の圧力で直径 $2 \mathrm{~cm}$, 高さ $2 \mathrm{~cm}$ に成形し, ガス炉内の共素地の上にのせ，さらに試料の 上に $\mathrm{FeO} 65.08 \%, \mathrm{Fe}_{2} \mathrm{O}_{3} 33.09 \%$ のロールスケール 奔直径 $2 \mathrm{~cm}$ に成形して置き, $1500^{\circ} \sim 1700^{\circ} \mathrm{C}$ で 1 3 時間ガス炉内に保持し, 上面 2 方向の線膨脹の測定の 平均值をとりバースチング膨脹を表わすことにした。

(b) 混合物の高温膨脹計法による実験 合成スピ ネル族鉱物の場合には $50: 50 \mathrm{wt} \%$ の 2 種スピネル族 鉣物の試料を瑪悩乳鉢でよく混合し, 直径 $1 \mathrm{~cm}$, 高さ $1.5 \mathrm{~cm}$ の大きさに $1000 \mathrm{~kg} / \mathrm{cm}^{2}$ の成形圧で成形し, 山 内, 鈴木の高温膨脹計 ${ }^{26}$ 䘮使用し, 試料を $31 \mathrm{~g} / \mathrm{cm}^{2}$ の 加圧下に $1000^{\circ} \mathrm{C}$ までは $10^{\circ} \mathrm{C} / \mathrm{min}, 1000^{\circ} \mathrm{C}$ 以上は $7^{\circ} \mathrm{C} /$ $\min$ の上昇率で加熱し，1/1000 mm または $1 / 100 \mathrm{~mm}$ のダイヤルゲージで膨脤を測定した。温度測定は Pt-87 $\% \mathrm{Pt} \cdot 13 \% \mathrm{Rh}$ 熱電対で行った.

クロムスピネル粒と酸化鉄との反応の場合にも合成ス ピネル族鉱物の膨脹測定の場合と同様に $50: 50$ 混合物 孝つくり実験した。

\section{(c) ラジオアイソトープ ${ }^{59} \mathrm{Fe}$ による拡散の実験}

外径 $10 \mathrm{~mm}$, 内径 $5 \mathrm{~mm}$, 高さ $10 \mathrm{~mm}$ の $\mathrm{MgO} \cdot \mathrm{Cr}_{2} \mathrm{O}_{3}$ 坩堝を加圧成形し, 内部に 4 本の $\mathrm{Pt}$ 線を対角線が直角 になるよらに設置し， ${ }^{59} \mathrm{Fe}$ を含む酸化鉄をいれ，
Table 6. The bursting expansions of binary mixtures by the dilatometric method and temperatures showing the maximum expansion.

\begin{tabular}{|c|c|c|}
\hline System & $\begin{array}{l}\text { Bursting } \\
\text { expansion }\end{array}$ & $\begin{array}{l}\text { Temperature } \\
\text { showing the } \\
\text { maximum } \\
\text { expansion }\end{array}$ \\
\hline $\mathrm{FeO} \cdot \mathrm{Fe}_{2} \mathrm{O}_{3}-\mathrm{FeO} \cdot \mathrm{Cr}_{2} \mathrm{O}_{3}$ & $7.30 \%$ & $1320^{\circ} \mathrm{C}$ \\
\hline $\mathrm{FeO} \cdot \mathrm{Al}_{2} \mathrm{O}_{3}$ & 1.00 & 1400 \\
\hline $\mathrm{MgO} \cdot \mathrm{Cr}_{2} \mathrm{O}_{3}$ & 3.38 & 1370 \\
\hline $\mathrm{MgO} \cdot \mathrm{Al}_{2} \mathrm{O}_{3}$ & 2.62 & 1320 \\
\hline $\mathrm{MgO} \cdot \mathrm{Fe}_{2} \mathrm{O}_{3}$ & 1.37 & 1180 \\
\hline $\mathrm{FeO} \cdot \mathrm{Cr}_{2} \mathrm{O}_{3}-\mathrm{FeO} \cdot \mathrm{Al}_{2} \mathrm{O}_{3}$ & - & - \\
\hline $\mathrm{FeO} \cdot \mathrm{Fe}_{2} \mathrm{O}_{3}$ & 7.30 & 1300 \\
\hline $\mathrm{MgO} \cdot \mathrm{Cr}_{2} \mathrm{O}_{3}$ & 1.13 & 1300 \\
\hline $\mathrm{MgO} \cdot \mathrm{Al}_{2} \mathrm{O}_{3}$ & 1.74 & 1250 \\
\hline $\mathrm{MgO} \cdot \mathrm{Fe}_{2} \mathrm{O}_{3}$ & 6.64 & 1370 \\
\hline $\mathrm{FeO} \cdot \mathrm{Al}_{2} \mathrm{O}_{3}-\mathrm{FeO} \cdot \mathrm{Cr}_{2} \mathrm{O}_{3}$ & - & - \\
\hline $\mathrm{FeO} \cdot \mathrm{Fe}_{2} \mathrm{O}_{3}$ & 1.00 & 1400 \\
\hline $\mathrm{MgO} \cdot \mathrm{Cr}_{2} \mathrm{O}_{3}$ & 3.50 & 1400 \\
\hline $\mathrm{MgO} \cdot \mathrm{Al}_{2} \mathrm{O}_{3}$ & 1.06 & 1270 \\
\hline $\mathrm{MgO} \cdot \mathrm{Fe}_{2} \mathrm{O}_{3}$ & 1.12 & 1260 \\
\hline $\mathrm{MgO} \cdot \mathrm{Cr}_{2} \mathrm{O}_{3}-\mathrm{FeO} \cdot \mathrm{Cr}_{2} \mathrm{O}_{3}$ & 1.13 & 1300 \\
\hline $\mathrm{FeO} \cdot \mathrm{Al}_{2} \mathrm{O}_{3}$ & 3.50 & 1400. \\
\hline $\mathrm{FeO} \cdot \mathrm{Fe}_{2} \mathrm{O}_{3}$ & 3.38 & 1370 \\
\hline $\mathrm{MgO} \cdot \mathrm{Al}_{2} \mathrm{O}_{3}$ & 1.48 & 1600 \\
\hline $\mathrm{MgO} \cdot \mathrm{Fe}_{2} \mathrm{O}_{3}$ & 1.16 & 1300 \\
\hline $\mathrm{MgO} \cdot \mathrm{Al}_{2} \mathrm{O}_{3}-\mathrm{FeO} \cdot \mathrm{Cr}_{2} \mathrm{O}_{3}$ & 1.74 & 1250 \\
\hline $\mathrm{FeO} \cdot \mathrm{Al}_{2} \mathrm{O}_{3}$ & 1.06 & 1270 \\
\hline $\mathrm{FeO} \cdot \mathrm{Fe}_{2} \mathrm{O}_{3}$ & 2.62 & 1320 \\
\hline $\mathrm{MgO} \cdot \mathrm{Cr}_{2} \mathrm{O}_{3}$ & 1.48 & $1600^{\circ}$ \\
\hline $\mathrm{MgO} \cdot \mathrm{Fe}_{2} \mathrm{O}_{3}$ & 0.92 & 1300 \\
\hline $\mathrm{MgO} \cdot \mathrm{Fe}_{2} \mathrm{O}_{3}-\mathrm{FeO} \cdot \mathrm{Cr}_{2} \mathrm{O}_{3}$ & 6.64 & 1370 \\
\hline $\mathrm{FeO} \cdot \mathrm{Al}_{2} \mathrm{O}_{3}$ & 1.12 & 1260 \\
\hline $\mathrm{FeO} \cdot \mathrm{Fe}_{2} \mathrm{O}_{3}$ & 1.37 & 1180 \\
\hline $\mathrm{MgO} \cdot \mathrm{Cr}_{2} \mathrm{O}_{3}$ & 1.16 & 1300 \\
\hline $\mathrm{MgO} \cdot \mathrm{Al}_{2} \mathrm{O}_{3}$ & 0.92 & 1300 \\
\hline
\end{tabular}


る場合，L型：室温から $1600^{\circ} \mathrm{C}$ までバースチング膨脹 を示さず，収縮もなく膨脹して行く場合と 3 種になる。

E型としては

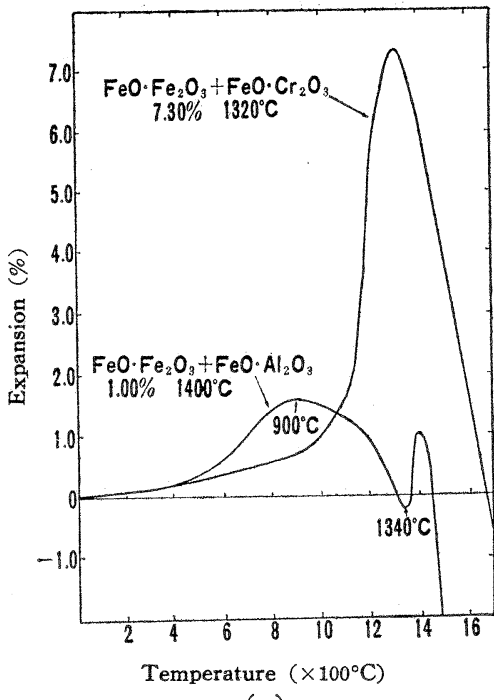

(a)

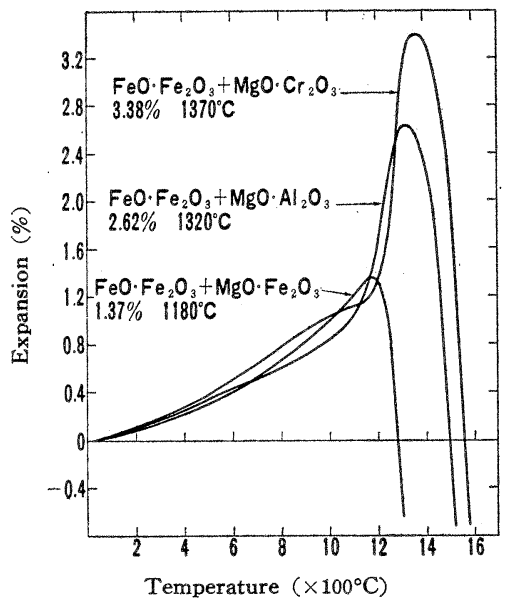

(b)

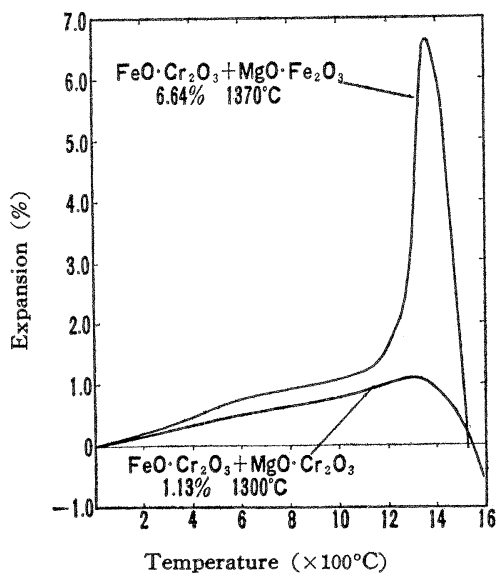

(c)

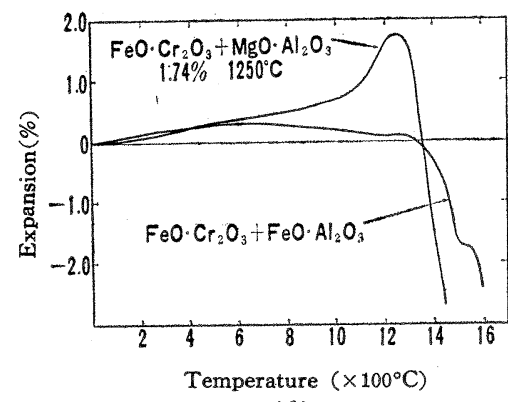

(d)

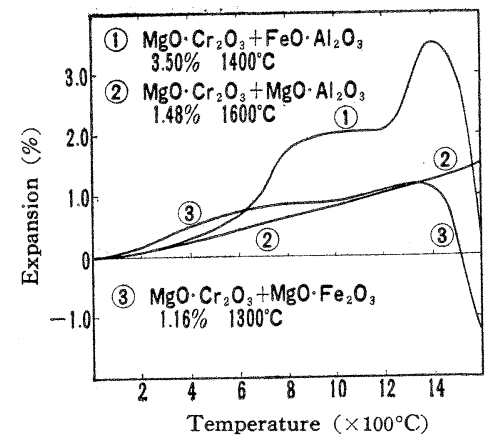

(e)
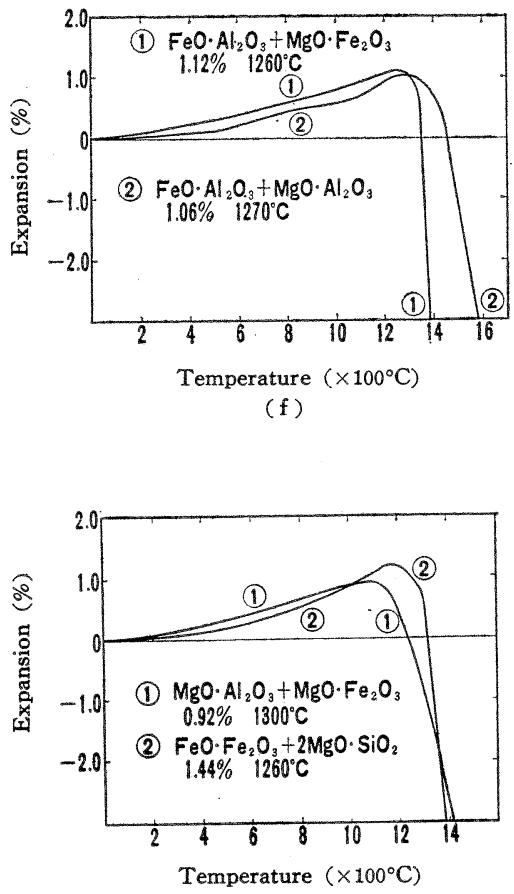

(g)

Fig. 2. The bursting expansions of the binary spinel mixtures by means of the dilatometric method.

$\mathrm{FeO} \cdot \mathrm{Fe}_{2} \mathrm{O}_{3}-\mathrm{MgO} \cdot \mathrm{Al}_{2} \mathrm{O}$ $\mathrm{FeO} \cdot \mathrm{Cr}_{2} \mathrm{O}_{3}$ $\mathrm{MgO} \cdot \mathrm{Al}_{2} \mathrm{O}_{3}$ $\mathrm{MgO} \cdot \mathrm{Cr}_{2} \mathrm{O}_{3}$

$\mathrm{FeO} \cdot \mathrm{Cr}_{2} \mathrm{O}_{3}-\mathrm{FeO} \cdot \mathrm{Fe}_{2} \mathrm{O}_{3}$ $\mathrm{MgO} \cdot \mathrm{Al}_{2} \mathrm{O}_{3}$ $\mathrm{MgO} \cdot \mathrm{Fe}_{2} \mathrm{O}_{3}$

$\mathrm{FeO} \cdot \mathrm{Al}_{2} \mathrm{O}_{3}-\mathrm{FeO} \cdot \mathrm{Fe}_{2} \mathrm{O}_{3}$ $\mathrm{MgO} \cdot \mathrm{Cr}_{2} \mathrm{O}_{3}$

$\mathrm{MgO} \cdot \mathrm{Al}_{2} \mathrm{O}_{3}-\mathrm{FeO} \cdot \mathrm{Cr}_{2} \mathrm{O}_{3}$ $\mathrm{FeO} \cdot \mathrm{Fe}_{2} \mathrm{O}_{3}$

$\mathrm{MgO} \cdot \mathrm{Cr}_{2} \mathrm{O}_{3}-\mathrm{FeO} \cdot \mathrm{Al}_{2} \mathrm{O}_{3}$

$\mathrm{FeO} \cdot \mathrm{Fe}_{2} \mathrm{O}_{3}$

$\mathrm{MgO} \cdot \mathrm{Fe}_{2} \mathrm{O}_{3}-\mathrm{FeO} \cdot \mathrm{Cr}_{2} \mathrm{O}_{3}$ などであり， $\mathrm{FeO} \cdot \mathrm{Fe}_{2} \mathrm{O}_{3}$ $\mathrm{FeO} \cdot \mathrm{Cr}_{2} \mathrm{O}_{3}$ の場合には図 一2 で示すように $1000^{\circ} \mathrm{C}<$ らいから膨脹係数が大きくな り， $1200^{\circ} \mathrm{C}$ くらいから急激 な膨脹を示している. $1320^{\circ} \mathrm{C}$ くらいまでこの膨脹は続き， それから収縮を示している。 $1320{ }^{\circ} \mathrm{C} く ら い に$ おる膨 脹は $7.30 \%$ であり, 次が $\mathrm{FeO} \cdot \mathrm{Fe}_{2} \mathrm{O}_{3}$ と $\mathrm{MgO} \cdot \mathrm{Cr}_{2} \mathrm{O}_{3}$ との膨脹は $6.64 \%, 1370^{\circ} \mathrm{C}$ である。他は $4 \%$ となって ずっと小さくなる。

$\mathrm{S}$ 型としては

$\mathrm{FeO} \cdot \mathrm{Fe}_{2} \mathrm{O}_{3}-\mathrm{MgO} \cdot \mathrm{Fe}_{2} \mathrm{O}_{3}$ $\mathrm{FeO} \cdot \mathrm{Cr}_{2} \mathrm{O}_{3}-\mathrm{FeO} \cdot \mathrm{Al}_{2} \mathrm{O}_{3}$ $\mathrm{MgO} \cdot \mathrm{Cr}_{2} \mathrm{O}_{3}$

$\mathrm{FeO} \cdot \mathrm{Al}_{2} \mathrm{O}_{3}-\mathrm{FeO} \cdot \mathrm{Cr}_{2} \mathrm{O}_{3}$ $\mathrm{MgO} \cdot \mathrm{Al}_{2} \mathrm{O}_{3}$. $\mathrm{MgO} \cdot \mathrm{Fe}_{2} \mathrm{O}_{3}$ $\mathrm{MgO} \cdot \mathrm{Al}_{2} \mathrm{O}_{3}-\mathrm{FeO} \cdot \mathrm{Al}_{2} \mathrm{O}_{3}$ $\mathrm{MgO} \cdot \mathrm{Fe}_{2} \mathrm{O}_{3}$

$\mathrm{MgO} \cdot \mathrm{Cr}_{2} \mathrm{O}_{3}-\mathrm{FeO} \cdot \mathrm{Cr}_{2} \mathrm{O}_{3}$ $\mathrm{MgO} \cdot \mathrm{Fe}_{2} \mathrm{O}_{3}$

$\mathrm{MgO} \cdot \mathrm{Fe}_{2} \mathrm{O}_{3}-\mathrm{FeO} \cdot \mathrm{Al}_{2} \mathrm{O}_{3}$ $\mathrm{FeO} \cdot \mathrm{Fe}_{2} \mathrm{O}_{3}$

$\mathrm{MgO} \cdot \mathrm{Fe}_{2} \mathrm{O}_{3}-\mathrm{MgO} \cdot \mathrm{Al}_{2} \mathrm{O}_{3}$ : $\mathrm{MgO} \cdot \mathrm{Cr}_{2} \mathrm{O}_{3}$

などである.

$\mathrm{L}$ 型としては $\mathrm{MgO} \cdot \mathrm{Cr}_{2} \mathrm{O}_{3}$ $-\mathrm{MgO} \cdot \mathrm{Al}_{2} \mathrm{O}_{3}$ などであり， $1600^{\circ} \mathrm{C}$ までほとんど直線的 に膨脹している。 


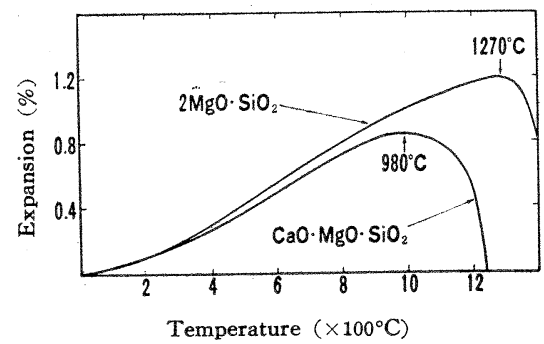

Fig. 3. Thermal expansion curves of forsterite and monticellite synthesized at $1300^{\circ} \mathrm{C}$.

珪酸塩と酸化鉄との反応を スピネル族鉱物と同様の条件 で測定した。珪酸塩としては フォルステライト, モンチセ ライトの 2 種で, 成形後 $1300^{\circ} \mathrm{C}$ に焼成した試料とフ オルステライトに酸化鉄を混 合したものの膨脹を図-2(g), 3 に示した. フォルステライ トと酸化鉄との膨脹は急激な バースチング膨脹がなく， $1100^{\circ} \mathrm{C}$ から収縮している。

クロム鉄鉣から融剤によっ て純化分離したクロムスピネ ル粒と酸化鉄との混合物の膨 脹は 図-4に示した。この膨 脹図から，クロムスピネル粒 と酸化鉄との膨脹は $\mathrm{E}$ 型, $\mathrm{S}$ 型の 2 種が認められ，L型は 認められなかった。

クロムスピネル粒のバース チング膨脹は著者の採用した 実験条件下で, $1200^{\circ} \mathrm{C} く ら$ いから膨脹係数が大きくなる ようである、最大膨脹率を示 す温度は $1400^{\circ} \sim 1500^{\circ} \mathrm{C}$ であ りことに $1460^{\circ} \sim 1500^{\circ} \mathrm{C}$ の 間に集中している。最大線膨 脹率は $2.07 \%$ が最大であ り，一般に $2 \%$ 以下である。

$\mathrm{E}$ 型としては, No. 1 広 瀬, No. 3 八田, No. 4 富 本静内, No. 6 若松, No. 7 赤石, No. 8 比島, No. 9 比 島, No. 10 八田本山混合, No. 11 富本糠平, No. 13 日 東, No. 14 土谷幌加内, No. 15 八田八幡, No. 16 八田本 山，No. 17 日東水洗などで

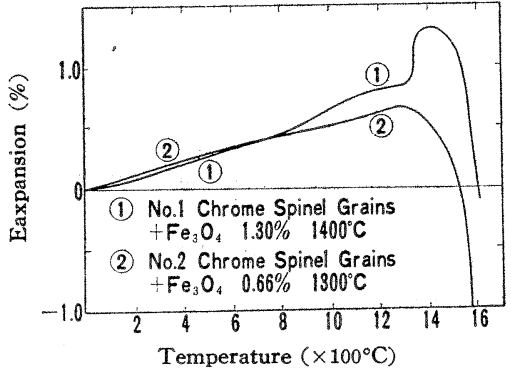

(a)

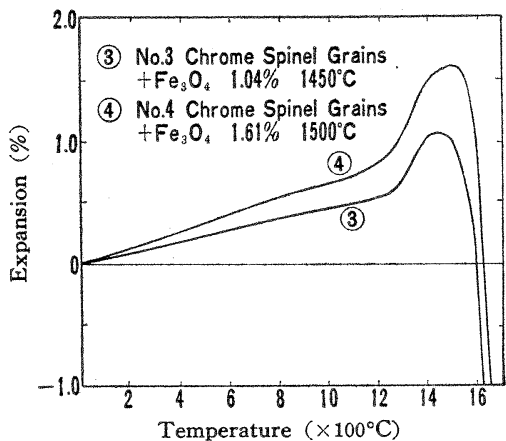

(b)

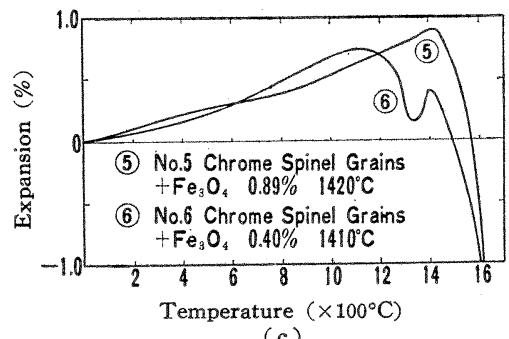

(c)

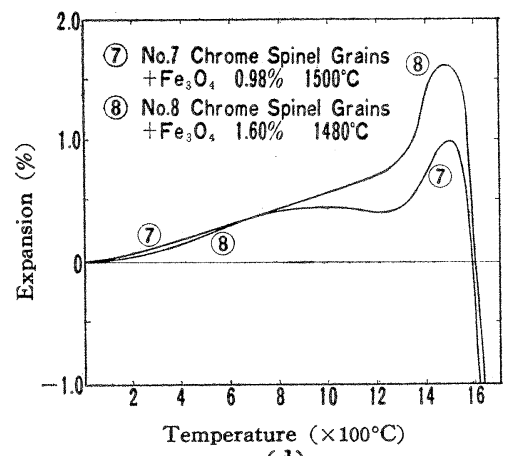

(d)

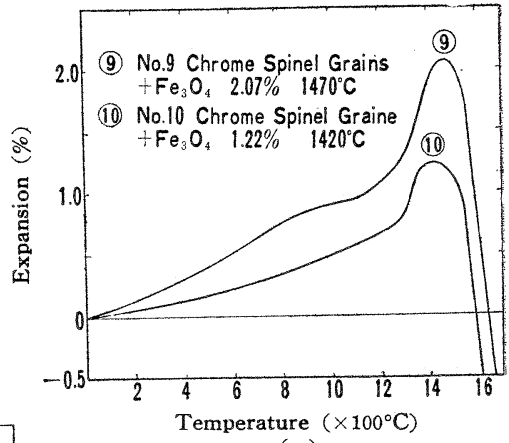

(e)

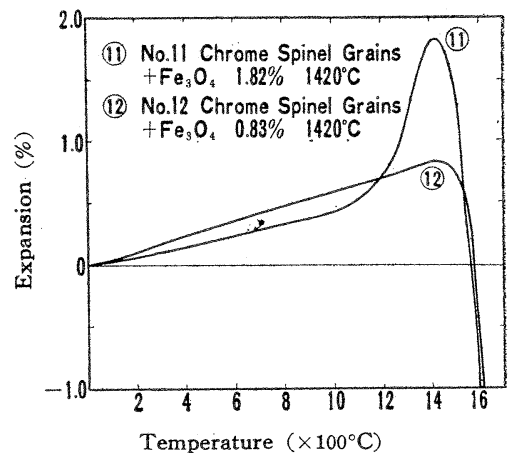

(f)

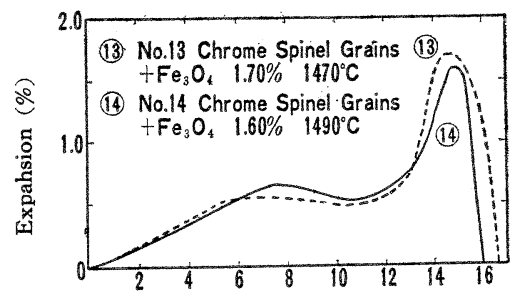

Temperature $\left(\times 100^{\circ} \mathrm{C}\right)$

(g)

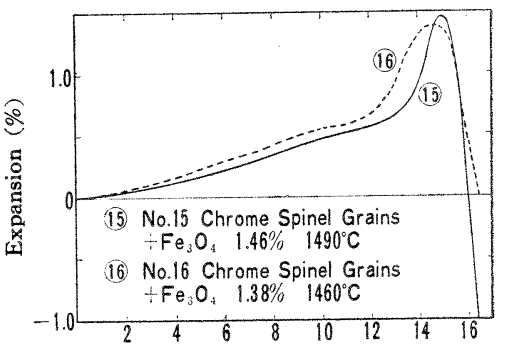

Temperature $\left(\times 100^{\circ} \mathrm{C}\right)$

(h)

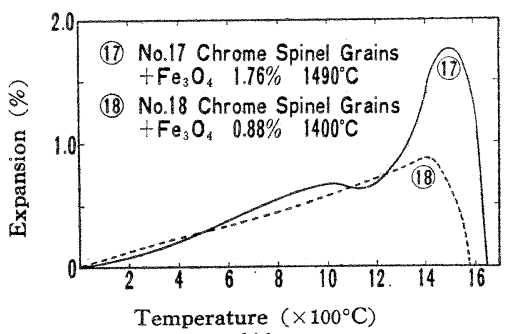

(i)

Fig. 4. The bursting expansions of the chrome spinel grains with magnetite by the dilatometric method. 
あり，S型としては，No. 2 芋原, No. 5 稲積, No. 12 日野上, No. 18 キューバ (No.. 19 マシンロックは試 験しなかった）などであった。

\section{（2）ボタン法によるバースチングの実験}

試験温度を $1500^{\circ} \mathrm{C}, 1620^{\circ} \mathrm{C}$ の 2 水準にとって試験す ると，表一7，8 のようで $1500^{\circ} \mathrm{C}$ では膨脹を示さず， かえって収縮を示している。酸化鉄は $1560^{\circ} \mathrm{C}$ 以上で熔 融し， $1620^{\circ} \mathrm{C}$ で 1 時間保持した場合，試料はバースチ ング膨脹を示しており, 酸化鉄量が増加するにつれてバ 一スチング量も増加している。高さ $2 \mathrm{~cm}$, 直径 $2 \mathrm{~cm}$ の 試験体の大きさの場合に，酸化鉄量は $5 \mathrm{~g}$ 前後すなお ち $1.5 \mathrm{~g} / \mathrm{cm}^{2}$ 前後がよく, ボタン法の場合には反応速 度がおそいために耐火物上部の酸化鉄が熔融することが 望ましいことがわかった。バースチングの試験温度につ ฟて恃，イギリスで $1600^{\circ}, 1650^{\circ}, 1700^{\circ} \mathrm{C}$ の 3 種水準 について試験をし， $1600^{\circ}, 1650^{\circ} \mathrm{C}$ 、の採用を再現性の点 から $1700^{\circ} \mathrm{C}$ よりすすめており， $1600^{\circ} \mathrm{C}$ は空気中に おける酸化鉄の融点に近いので, Zerfoss and Davis は $1625^{\circ} \sim 1630^{\circ} \mathrm{C}$ をすすめている。そこで著者は $1650^{\circ}$ $\pm 20^{\circ} \mathrm{C}$ を実験条件の一つとして採用することにした。

$1650^{\circ} \mathrm{C}$ の試験温度に 保持する時間は，1 時間保持, 3 時間保持の 2 水準で実験してみると, 表-9 の通りで, 3 時間加熱の方が 1 時閒加熱の場合より再現性のよいこ

Table 7. The bursting expansion of the chrome ore at $1500^{\circ} \mathrm{C}$ by the bottom method.

$\begin{array}{lccc} & \begin{array}{c}\text { Upper } \\ \text { diameter } \\ (\mathrm{cm})\end{array} & \begin{array}{c}\text { Lower } \\ \text { diameter } \\ (\mathrm{cm})\end{array} & \begin{array}{c}\text { Height } \\ (\mathrm{cm})\end{array} \\ \text { Before experiment } & 2.055 & 2.055 & 2.530 \\ \text { After experiment } & 2.055 & 2.040 & 2.046 \\ \text { Expansion (\%) } & 0.0 & -0.54 & -2.96 \\ \text { Total expansion } & -3.50 & & \\ - \text {. Con } & & & \end{array}$

Table 8. Relation between the bursting expansion of the chrome ore and amount of roll scale at $1600^{\circ} \mathrm{C}$ experiment by the bottom method.

$\begin{array}{rccl} & \begin{array}{c}\text { Bursting } \\ \text { expansion } \\ (\%)\end{array} & \begin{array}{c}\text { Amount of } \\ \text { roll scale } \\ (\mathrm{g})\end{array} & \begin{array}{c}\text { Length of } \\ \text { changed part } \\ (\mathrm{cm})\end{array} \\ \text { No. } 1 & 25.1 & 3.0 & 1.2 \\ 2 & 28.3 & 5.4 & 1.9 \\ 3 & 30.0 & 9.1 & \text { more than } 2.3 \\ 4 & 32.3 & 15.2 & \text { more than } 2.3 \\ 5 & 36.3 & 19.2 & \text { more than } 2.3\end{array}$

Table 9. Relation between the bursting expansion of the chrome ores by the bottom method and holding time at $1650^{\circ} \mathrm{C}$.

$\begin{array}{lrcccc} & \text { I } & \text { II } & \text { III } & \text { IV } & \begin{array}{c}\text { Average } \\ \text { I \& II }\end{array} \\ \text { No. } 1 \text { Hirose } & 3 \mathrm{hrs} & 3 \mathrm{hrs} & 1 \mathrm{hr} & 1 \mathrm{hr} & 3 \mathrm{hrs} \\ 4 \text { Tomimoto Shizunai } & 21.2 & 18.6 & 40.0 & 23.6 & 19.9 \\ \text { 5 Inazumi } & 11.3 & -10.5 & -1.58 & -8.42 & -10.9 \\ 7 \text { Akaishi } & 13.6 & 13.6 & 23.8 & 13.0 & 13.6 \\ 11 \text { Tomimoto Nukahira } & 4.24 & 1.72 & 20.3 & 13.8 & 1.48 \\ 14 \text { Tsuchiya Horokanai } & 18.8 & 13.21 & 20.4 & 13.6 & 3.81 \\ 17 \text { Nitto Washing } & 14.8 & 14.8 & 25.3 & 17.3 & 16.2 \\ \text { 19 Masinloc } & 14.5 & 13.1 & 17.8 & 17.1 & 14.8 \\ \end{array}$

Table 10. The bursting expansion and the bursting tendency of the 14 chrome ores.

$\begin{array}{rlr}\text { No. } 1 \text { Hirose } & (\%) & 20.7 \\ 2 \text { Imobara } & 12.8 & 5 \\ 3 \text { Hatta } & 16.6 & 10 \\ 4 \text { Tomimoto Shizunai } & -5.8 & 8 \\ 5 \text { Inazumi } & 10.5 & 13 \\ 6 \text { Wakamatsu } & 19.7 & 11 \\ 7 \text { Akaishi } & 5.8 & 5 \\ 8 \text { Philippine } & 18.0 & 12 \\ 9 \text { Philippine } & 21.3 & 6 \\ 10 \text { Hatta Main Mixture } & 22.9 & 3 \\ 13 \text { Nitto } & 22.9 & 2 \\ 14 \text { Tsuchiya Horokanai } & 15.0 & 2 \\ 16 \text { Hatta Main } & 17.6 & 9 \\ 17 \text { Nitto Washihg } & 23.1 & 7 \\ - \text { : Contraction } & & \\ & & \end{array}$

とがわかった。

このようにしてきめられた実験条件下 $\left(1650^{\circ} \mathrm{C} \pm 20^{\circ}\right.$ C，3 時間保持）における 14 種ク口ム鉄鉱のバースチ ング膨脹およびバースチング傾向は表-10の通りで No. 17 日東水洗鉱が $23.1 \%$ で最大であった。(以下次号)

\section{Dr. G. Wagner 記念公開学術講演会（第 3 回）}

Dr. G. Wagner の業績を記念し, 無機材料あるいは窯業材料に関する研究面のいっそうの進展を促進するために頭記講 演会を下記により開きます。

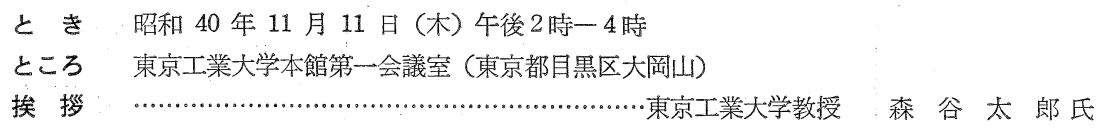

X線回析による案業材料研究の最近の進歩……東京大学教授 理博 定 永 両 一 氏 主 催 東京工業大学室友会 (代表 田賀井秀夫) 電 726-1111 内線 575

後 援東京工業大学突業同空会 